\title{
A note on the use of prisons as environments for investigation of crowding*
}

\section{PAUL PAULUS, GARVIN McCAIN, and VERNE COX University of Texas at Arlington, Arlington, Texas 76010}

Some general considerations involved in studying the effects of crowding on humans are considered. It is proposed that prisons provide an excellent setting for such research since they contain a variety of realistically crowded conditions. The effects of spatial and social crowding are found to be separable in prisons.

The effect of crowding (high population concentration) in animals has been extensively examined. However, there is little experimental or observational evidence regarding the effect of high population concentration on humans. All too often, the dramatic behavioral pathology of crowded rats described by Calhoun (1962) is used as a basis for predicting the responses of humans to conditions of high population concentration. While there is little doubt that humans will display behavioral pathology, if sufficiently crowded, we have no evidence indicating the kind of pathological changes that would occur or at what degree of crowding they would emerge. Nor do we know the relative contributions of reduced space and increased interpersonal contact to whatever pathological effects might be generated by high levels of crowding. What is needed, but to date does not exist, are extensive controlled investigations of the effects of variations of population concentration on humans. This conclusion is not unique to us, but is shared by others and has been amply documented in a recent review by Zlutnic \& Altman (1971) and more briefly by Stokols (1972).

Statistical surveys have been few in number and have yielded conflicting results. Schmitt's statistical surveys $(1957,1966)$ indicated that high population concentration can affect several measures of social pathology. On the other hand, Winsborough (1965) argued that controlling for socioeconomic factors greatly diminishes the relationship between high population concentration and social pathology. More recently, Galle, Gove, \& McPherson (1972) have demonstrated strong positive relationships between measures of population concentration and social pathology, independent of socioeconomic factors.

The few experimental studies of crowding that have

*Part of this material was presented at the Psychonomic Society meetings, St. Louis, November 1972. Order of authorship in this and other papers in this series was determined by random selection. The Hogg Foundation for Mental Health and The University of Texas at Arlington provided funds for feasibility studies, which involved a survey of 10 prisons. These institutions ranged from minimum security to maximum security. Thanks are due to the many helpful institution officials, in particular L. M. Connett and George Horvat of the Federal Correctional Institution, Texarkana, Texas. been reported have also yielded conflicting results and in some cases are plagued by poor design and confounded variables. Freedman, Klevansky, \& Ehrlich (1971) and Freedman, Levy, Buchanan, \& Price (1972) conducted two experimental studies explicitly designed to examine crowding effects in humans. In the initial study (Freedman et al, 1971), no effects of group size and available space on task performance were observed. More recently, Freedman et al (1972) reported that group size and available space does affect aggressiveness in sexually homogeneous groups, but, as in the earlier work, no effects of group size and available space were observed in sexually heterogeneous groups. In Freedman's studies, the duration of exposure to various degrees of crowding was limited to a few hours. In contrast, Smith \& Haythorn (1972) have examined the effects on highly selected naval volunteers of limited variation in space (70 vs $200 \mathrm{cu} \mathrm{ft}$ of unobstructed space) and group size ( 2 men vs 3 men) over a 21 -day period. Their results indicate that low available space combined with larger group size yielded the highest level of psychological stress. Hostility, as measured by a hostility scale (Berkun, Burdick, \& Woodring, 1963), was more evident under the less crowded conditions.

In brief, the evidence, experimental and otherwise, regarding crowding effects on humans is scanty and/or conflicting. Statistical surveys provide little opportunity for controlled investigation and laboratory studies are of limited value because realistic stress levels cannot be ethically achieved. Ethical considerations aside, in laboratory studies, an individual's expectation regarding his ability to terminate crowded conditions is probably an important determinant of his reactions to crowding. These considerations led us to exploration of field settings as environments in which to assess the effects of crowding on humans. The choice of a field setting was guided by two primary considerations. First, the setting should include living conditions in which individuals are exposed to various degrees of crowding over relatively long periods of time (days-months). Secondly, the living arrangements should enable analysis of the independent effects of social and spatial density. Social density was defined as the number of potential two-person interactions, $\left(\mathrm{N}^{2}-\mathrm{N}\right) / 2$, while spatial density was defined as amount of square footage per man. Stokols (1972) has recently conceptualized the problem of crowding in a similar way.

A number of different field settings were considered, and most either did not meet one of the basic requirements or had some other major disadvantage. For example, dormitories in educational institutions do not ordinarily have a large range of degrees of crowding; 
Table 1

Cell Arrangements: Dallas County Jail

\begin{tabular}{cllcc}
\hline $\begin{array}{c}\text { Number } \\
\text { of } \\
\text { Occu- } \\
\text { pants }\end{array}$ & Length & Width & $\begin{array}{c}\text { Square } \\
\text { Feet } \\
\text { Per } \\
\text { Man }\end{array}$ & $\begin{array}{c}\text { Social } \\
\text { Den- } \\
\text { sity } \\
\text { Index }\end{array}$ \\
\hline 8 & $15 \mathrm{ft} 11$ in. & $8 \mathrm{ft}$ & 15 & 28 \\
8 & $13 \mathrm{ft}$ & $6 \mathrm{ft} 6$ in. & 10 & 28 \\
4 & $13 \mathrm{ft}$ & $5 \mathrm{ft} 6$ in. & 18 & 6 \\
4 & $17 \mathrm{ft}$ & $8 \mathrm{ft}$ & 34 & 6
\end{tabular}

Examples of cell arrays that allow examination of variations in spatial density with social density held constant.

$\begin{array}{rllll}8 & 15 \mathrm{ft} 11 \text { in. } & 8 \mathrm{ft} & 15 & 28 \\ 6 & 13 \mathrm{ft} & 6 \mathrm{ft} 8 \mathrm{in} . & 15 & 15 \\ 8 & 13 \mathrm{ft} & 6 \mathrm{ft} 6 \mathrm{in} . & 10 & 28 \\ 12 & 15 \mathrm{ft} 11 \text { in. } & 8 \mathrm{ft} & 10 & 66\end{array}$

Examples of cell arrays that allow examination of variations in social density with spatial density held constant.

submarine crews are self-selected and are likely to be atypical in their responses to crowding; tenement populations spend varying periods of time away from the housing units. On the basis of such considerations, we finally concluded that prisons might provide the appropriate setting for investigation of the problem.

On-site surveys of 10 prisons, ranging from municipal jails to maximum-security state and federal prisons in various parts of the country, indicated that prisons could provide an excellent setting for the investigation of crowding in humans. Prisons provide a number of advantages which, we believe, outweigh the disadvantages of employing a prison population for crowding research. Prisons, in many cases, provide a wide range of variation in housing-unit size and number of occupants within housing units. These characteristics provide sustained exposure to a wide range of spatial and social density as well as at least partial independence of these two dimensions. Opportunities are available for long-term observation and testing in a population that is reasonably heterogeneous with regard to a number of personality and biographical characteristics. Biographical data are easily obtained, particularly in federal institutions. Volunteer rates are satisfactory, particularly for the relatively innocuous procedures in most behavioral testing.

Table 2

Texarkana Federal Correctional Institution

\begin{tabular}{cccc}
\hline & $\begin{array}{c}\text { Number } \\
\text { of } \\
\text { Occupants }\end{array}$ & $\begin{array}{c}\text { Square } \\
\text { Feet Per } \\
\text { Man }\end{array}$ & $\begin{array}{c}\text { Social } \\
\text { Density } \\
\text { Index }\end{array}$ \\
\hline \multirow{2}{*}{ I } & 44 & 30.7 & 946 \\
& 28 & 49.6 & 378 \\
II & 33 & 83.6 & 528 \\
& 21 & 84.3 & 210
\end{tabular}

Example of variations in population concentration with social and spatial density confounded in the first example and with spatial density constant and social density varied in second example.
Tables 1 and 2 illustrate variation in spatial and social density available when the number of cell occupants match designed capacity in housing units of Dallas County Jail, Dallas, Texas, and Texarkana Federal Correctional Institution, Texarkana, Texas. Often, the number of cell and dorm occupants vary over time, providing additional variation in spatial and social density. These data illustrate that variations in cell sizes and number of occupants can provide wide and at least partially independent variation of spatial and social density conditions.

Behavioral testing in prison environments must be unobtrusive and compatible with prison regimens. For example, to study crowding effects, we have used a behavioral task that is an adaptation of a test designed to measure one's criterion of being crowded (Desor, 1972) and palmar sweat as a measure of stress.

Out initial studies in the Texarkana Federal Correctional Institution indicate that social density is positively related to palmar sweat scores, whereas the Desor task has thus far yielded mixed results. ${ }^{1}$

In summary, architectural and occupancy data obtained from site surveys and initial studies at the Texarkana Federal Correctional Institution support our contention that prison environments provide an excellent setting in which to study the psychological effects of sustained exposure to a wide range of spatial and social density conditions.

\section{REFERENCES}

Berkun, M. M., Burdick, H. A., \& Woodring, T. M. A checklist for feelings of hostility. Unpublished manuscript, Quinnipiac College, Hamden, Connecticut, 1963.

Calhoun, J. Population density and social pathology. Scientific American, 1962, 206, 139-148.

Desor, J. A. Toward a psychological theory of crowding. Journal of Personality \& Social Psychology, 1972, 21, 79-83.

Freedman, J. L., Levy, A. S., Buchanan, R. W., \& Price, J. Crowding and human aggressiveness. Journal of Experimental Social Psychology, 1972, 8, 528-548.

Freedman, J. L., Klevansky, S., \& Ehrlich, P. R. The effects of crowding on human task performance. Journal of Applied Social Psychology, 1971, 1, 7-25

Galle, O. R., Gove, W. R., \& McPherson, J. M. Population density and pathology: What are the relations for man? Science, 1972, 176, 23-30.

Mason, J. W. Organization of psychoendocrine mechanisms. Psychosomatic Medicine. 1968, 30, 565-791.

Schmitt, R. C. Density, delinquency and crime in Honolulu. Sociology \& Social Research, 1957, 41, 274-276.

Schmitt, R. C. Density, health and social disorganization. Journal of American Institute of Planners, 1966, 32, 38-40.

Smith, S., \& Haythorn, W. W. Effects of compatibility, crowding, group size and leadership seniority on stress, anxiety, hostility and annoyance in isolated groups. Journal of Personality \& Social Psychology, 1972, 21, 67-79.

Stokols, D. On the distinction between density and crowding: Some implications for future research. Psychological Review 1972, 79, 275-277.

Winsborough, H. The social consequences of high population density. Law \& Contemporary Problems, 1965, 30, 120-126.

Zlutnic, S., \& Altman, I. Crowding and human behavior. In J. F. Wohlwill and D. H. Carson (Eds.), Behavioral science and the problems of our environment. Washington, D.C: American Psychological Association, 1971.

\section{NOTE}

1. Urine correlates (catecholamines and steroids) of psychological stress provide a convenient way to assess stress associated with crowding (Mason, 1968). Urine samples are easily obtained, analyzed elsewhere, and minimize opportunity for contamination of stress measure with deception. We will introduce such measures in future studies.

(Received for publication March 25, 1973.) 